\title{
Sciendo
}

\section{Spontaneous bacterial peritonitis: update on diagnosis and treatment}

\author{
ROXANA-EMANUELA POPOIAG ${ }^{1}$, CARMEN FIERBINȚEANU-BRATICEVICI ${ }^{2,3}$ \\ ${ }^{1}$ Ovidius University Faculty of Medicine, Department of Internal Medicine, Constanța, Romania \\ ${ }^{2}$ Carol Davila University of Medicine and Pharmacy, Bucharest, Romania \\ ${ }^{3}$ University Emergency Hospital, Gastroenterology Department, Bucharest, Romania
}

\begin{abstract}
Spontaneous bacterial peritonitis (SBP) is a common complication in patients with liver cirrhosis, with an increased risk of mortality. For this reason, a diagnostic paracentesis should be performed in all patients with ascites and clinical features with high diagnostic suspicion. Although literature data abound in identifying new diagnostic markers in serum or ascites, they have not yet been validated. The final diagnosis requires the analysis of ascites and the presence of $>250 \mathrm{~mm}^{3}$ neutrophil polymorphonuclear (PMN) in ascites. If previous data showed that the most common microorganisms identified were represented by gram-negative bacteria, we are currently facing an increase in gram-positive bacteria and multidrug-resistant bacteria. Although prompt and effective treatment is required to prevent outcomes, this becomes challenging as first-line therapies may become ineffective leading to worsening prognosis and increased in-hospital mortality. In this paper we will make a brief review of existing data on the diagnosis and treatment of SBP.
\end{abstract}

Key words: spontaneous bacterial peritonitis, cirrhosis, paracentesis, multidrug-resistant organisms.

\section{INTRODUCTION}

Bacterial infections are common in patients with liver cirrhosis and an important cause of hospitalization in these patients. Infections can occur at admission or can develop during hospitalization in $25 \%-35 \%$ of cases, with an incidence 4-5 times higher than in the general population [1]. The most common infections are spontaneous bacterial peritonitis (SBP 27\%) followed by urinary tract infections (UTI 22\%) and pneumonia (19\%). A higher prevalence of pneumonia and UTI and a lower prevalence of SBP were found in Asian centres compared to centres in America and Europe [2].

SBP has been defined as a bacterial infection of the ascites fluid without an intraabdominal source of infection. Although when it was first discovered the mortality rate exceeded $90 \%$, it later dropped to about $20 \%$ through rapid diagnosis and treatment [3]. However, the prognosis is poor and the survival after the first episode at 1 year is $40 \%$ [4]. The objectives of this review were to summarize current diagnostic and treatment methods as well as to perform an assessment of new diagnostic markers and new treatment recommendations.

\section{DIAGNOSTIC METHODS}

According to the European Association for the Study of Liver (EASL) guideline, the diagnosis of SBP is based on a diagnostic paracentesis [3]. Delayed paracentesis is associated with an increased risk of mortality. Patients with early paracentesis showed a tendency to reduce mortality (5.5\% vs. $7.5 \%)$ compared with those with late paracentesis. Also, patients admitted during the weekend had a 1.12 times higher risk of mortality due to delayed paracentesis compared to patients admitted during the week $(50 \%$ weekend vs. $62 \%$ week). In patients diagnosed with SBP, the benefits were reflected in a shorter mean hospital stay and implicitly a lower cost [5]. Paracentesis performed $<12$ hours after hospitalization may improve short-term survival in patients with cirrhosis and ascites and each hour of delay has been associated with a $3.3 \%$ higher risk of in-hospital mortality [6].

The ideal anatomical location for performing a paracentesis has not been established, but the optimal location would be the one that avoids the inferior epigastric artery and has a deep pocket of fluid and the one that offers great 
safety in avoiding intestinal perforation [7]. Data are limited regarding when to perform paracentesis under ultrasonographic guidance. However, a retrospective study that included 70,000 paracenteses showed that the risk of bleeding decreased from $1.25 \%$ to $0.27 \%$ using ultrasonographic guidance [8].

Paracentesis for diagnostic purposes is recommended in patients with ascites grade 2 and 3 or in hospitalized patients for worsening ascites or any complication of liver cirrhosis [3]. Other indications are:

- Local symptoms and / or signs of peritonitis: abdominal pain, abdominal tenderness, vomiting, diarrhea, ileus

- Signs of systemic inflammation: hyper or hypothermia, chills, leukocyte modification, tachycardia / tachypnea

- Aggravation of liver function

- Hepatic encephalopathy

- Renal insufficiency

- Gastrointestinal bleeding [3].

Patients with SBP may be asymptomatic or may have various symptoms. A prospective, observational study performed on 144 patients who underwent paracentesis in the emergency department aimed to determine the predictive value of clinical manifestations and the physician clinical judgment in the diagnosis of SBP. The authors showed that a history of fever in the last 24 hours had a specificity of $81 \%$ but did not allow the differentiation between SBP and other sources of infections. Also, abdominal pain and tenderness had a diagnostic sensitivity of $94 \%$. In contrast, the physician's clinical judgment demonstrated a limited sensitivity of $77 \%$ and a specificity of $34 \%$ for the detection of SBP. However, data were insufficient in the diagnosis or exclusion of SBP [9].

Therefore, the definite diagnosis cannot be made only clinically but requires a paracentesis for diagnostic purposes with the analysis of ascites fluid. A PMN value $>250 \mathrm{~mm}^{3}$ confirms the diagnosis. Gold standard for counting neutrophils in ascites fluid is manual microscopy. Although it is an independent operator and can provide inconsistent results, it has proven to be more reliable than automatic counting [10]. An alternative may be flow cytometry, a new form of technology that has a sensitivity and specificity of approximately $100 \%$ for PMN detection> 250 $\mathrm{mm}^{3}[3,10,11]$. The culture of ascites fluid is necessary to guide antibiotic treatment but not to confirm the diagnosis [3].

There are several variants of SBP, namely:

- SBP with positive culture: $\mathrm{PMN} \geq 250 \mathrm{~mm}^{3}$ and present culture

- SBP with negative culture or neutrocytic ascites with negative cultures: $P M N \geq 250 \mathrm{~mm}^{3}$ and negative culture

- Bacterascitis: PMN $<250 \quad \mathrm{~mm}^{3}$ and positive culture $[3,10]$.

The differential diagnosis with secondary bacterial peritonitis is crucial given that although it is less common in patients with liver cirrhosis, it involves an increased risk of mortality [12]. Thus, if there is a high suspicion of secondary bacterial peritonitis (multiple microorganisms, a large number of neutrophils identified in ascites fluid or in case of an inadequate response to treatment) [3] it is useful to determine proteins, glucose, $\mathrm{LDH}$, carcinoembryonic antigen and alkaline phosphatase in differentiating the two entities [13].

\section{DIAGNOSTIC MARKERS}

The gold standard in the diagnosis of SBP is the PMN value in ascites fluid, but often paracentesis cannot be performed. For this reason, laboratory markers are useful for rapid diagnosis and for rapid prediction of response to initial treatment [14].

Procalcitonin (PCT), is a precursor to the thyroid hormone calcitonin, a 116 amino acid protein and is secreted by almost all parenchymal tissues in the body in response to TNF-alpha during bacterial infections starting to grow 4 hours after infection. It also has a long half-life of 25-30 hours and is undetectable in healthy people [15]. Results on the accuracy of PCT in the early detection of bacterial infection in liver cirrhosis, especially SBP, are controversial. The results of a meta-analysis that included 339 patients with cirrhosis and SBP were that serum PCT had a sensitivity of 0.82 and a specificity of 0.86 and an area under the curve (AUC) of 0.92 in the diagnosis of SBP [16]. In contrast, in the study by Lesińska et al. PCT values could not differentiate patients with SBP from those without SBP [17].

High-sensitivity $C$-reactive protein (hs$C R P)$ is more sensitive than CRP as an inflammatory marker. Guler et al showed that serum levels were significantly higher in patients with SBP and positive culture and bacterascitis compared to the control group and levels 
decreased significantly after 2 days of antibiotic treatment in patients with SBP [18].

In a study that included 100 patients with decompensated liver cirrhosis, divided into 2 groups, namely 50 patients with SBP and 50 patients with sterile ascites, it was shown that the mean levels of hs-CRP in ascites fluid were higher in patients with SBP compared to those without SBP. Also, the levels were lower 5 days after starting the antibiotic treatment or at discharge compared to those before starting the treatment [19].

Macrophage inflammatory protein type 1 Beta $(M I P-1 \quad \beta)$ belongs to the group of chemokines, which are known for their chemotactic and proinflammatory effects [20]. Serum levels did not differ in patients with SBP compared to those without SBP, however the ascites fluid values were significantly higher and a cut-off value of $69.4 \mathrm{pg} / \mathrm{ml}$ has a sensitivity of $80 \%$ and a specificity of $72.7 \%$, AUROC of 0.77 for the diagnosis of SBP [17].

Bacterial endotoxins are the main stimulus for the production of several proinflammatory cytokines such as tumor necrosis factor (TNF)- $\alpha$ and interleukin (IL)-6 and their levels in ascites fluid are significantly higher in patients with SBP than in those with sterile ascites $[10,20]$.

Lactoferrin is a product and marker of PMN activity [10] and values in ascites fluid may have clinical utility in differentiating patients with cirrhosis and SBP from those without SBP. A prospective study that included 102 patients with ascites showed that lactoferrin in ascites fluid has a sensitivity of $95.8 \%$ and a specificity of $74.4 \%$ and an area under the receiver operating characteristics (AUROC) of 0.898 in the diagnosis of SBP at a cut-off value of $51.4 \mathrm{ng} / \mathrm{mL}$ [21]. However, data are limited and require further studies to confirm the results.

Calprotectin is a protein derived from neutrophils, which is found in both plasma and stool, which is increased in inflammatory and infectious situations [22]. Following the analysis of 10 studies included in a metaanalysis, it was shown that the value of calprotectin in ascites fluid has a sensitivity of 0.91 and a specificity of 0.87 and AUC of 0.92 in the diagnosis of SBP and can be considered a promising diagnostic marker [23].

The test using leukocyte esterase reagent strips (LERS) is based on leukocyte esterase activity, are not specific for PMN and the interpretation of the colorimetric reaction is subjective [24]. Although initial data were encouraging in their usefulness in diagnosing SBP, a review that included analysis of 19 studies showed that there was heterogeneity in the number of patients included, the total number of ascites fluid samples, and the prevalence of SBP. The authors also conclude that the LERS test cannot be recommended due to the low sensitivity and high risk of falsenegative results, especially in patients with SBP and a low number of PMN [25].

There is limited evidence on other markers as well: interferon $\gamma$-induced protein 10 [26], receptor triggering receptor expressed on myeloid cells 1 [27], monocyte chemotactic protein 1 [28,29], liposaccharide binding protein [30], neutrophil gelatinase-associated lipocalin [31], homocysteine [32], amyloid A [33] but require future studies to be able to confirm their clinical utility in the diagnosis of SBP.

\section{THERAPEUTIC MEASURES}

The antibiotic treatment used to treat patients with SBP has changed over time. Initially, the EASL guideline developed in 2010 recommends as first-line treatment the administration of third generation cephalosporins (cefotaxime in a dose of $2 \mathrm{~g}$ every 12 hours or 8 hours for a period of 5 days) and as therapeutic options amoxicillin/clavulanic acid and quinolones such as ciprofloxacin and ofloxacin. Drawing attention to the fact that quinolone treatment should not be an option for patients using them for SBP prophylaxis, in areas of high resistance to this class, or in nosocomial cases [34].

Lately, we are facing an epidemiological change in the sense of increasing the number of infections with gram-positive bacteria and multidrug resistant bacteria. This may be due to the fact that patients with cirrhosis frequently require hospital care, recurrent hospitalizations or hospitalizations in intensive care units. Thus, the classification of acquired SBP in nosocomial and community is no longer satisfactory, and a new epidemiological category was introduced: health care-related infections [35]. The classification of SBP according to the acquisition method is shown in Table 1. 
Table 1

Classification of SBP by etiology

\begin{tabular}{|c|l|}
\hline Epidemiological category & \multicolumn{1}{|c|}{ Definition } \\
\hline Nosocomial & The diagnosis is made 48 hours after hospitalization [10] \\
\hline Community acquired & $\begin{array}{l}\text { The diagnosis is made within } 48 \text { hours of hospitalization in a } \\
\text { patient without direct contact with medical care [10] }\end{array}$ \\
\hline Health care related & $\begin{array}{l}\text { The diagnosis is made within 48 hours of hospitalization in a } \\
\text { patient with direct medical contact (for example, when a patient } \\
\text { has been admitted to a hospital or hemodialysis center or received } \\
\text { intravenous chemotherapy during the 30 days prior to infection, or } \\
\text { has been hospitalized for at least 2 days, or has undergone surgery } \\
3 \text { months before infection, or has lived in a nursing home or long- } \\
\text { term care facility [36] }\end{array}$ \\
\hline
\end{tabular}

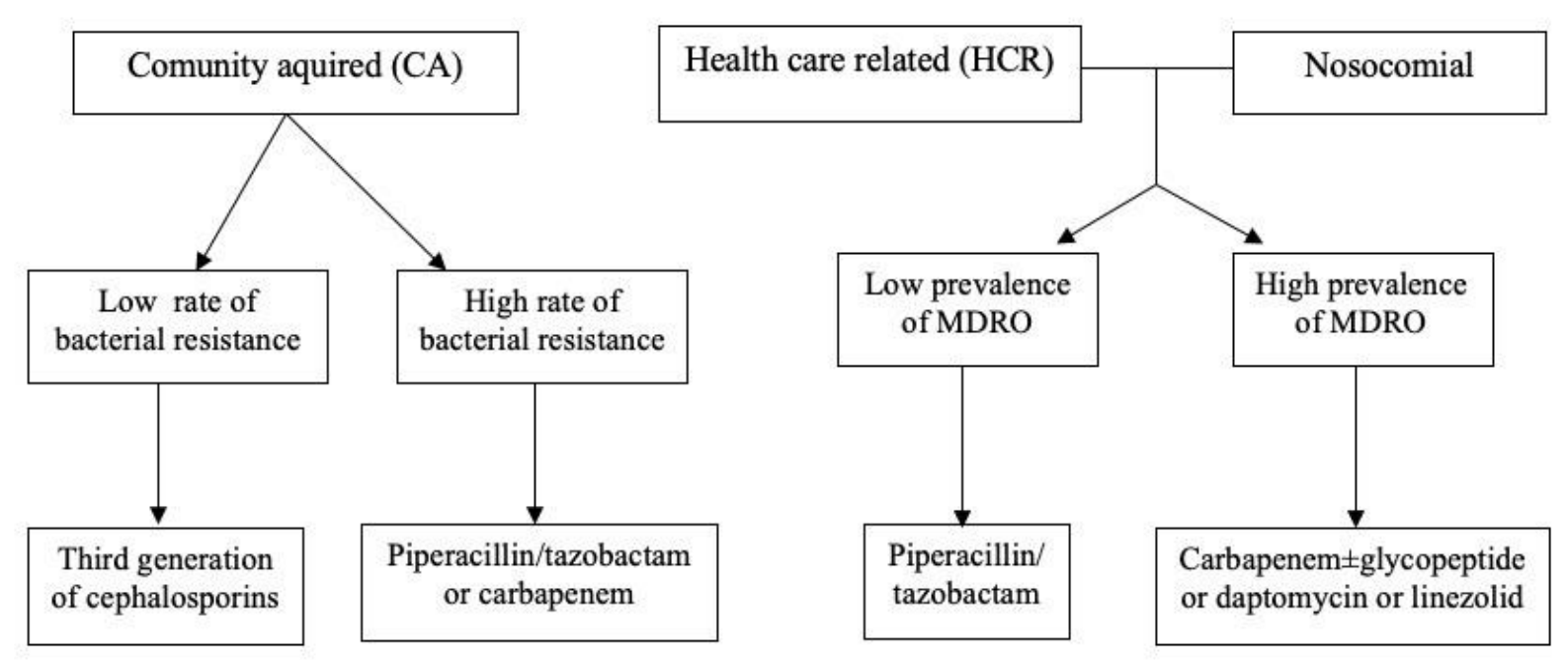

Figure 1. SBP treatment according to EASL guideline [3].

Given these changes, the current EASL guideline highlights the importance of infection severity as well as local resistance profile in guiding the empirical treatment of SBP. The treatment algorithm is shown in Figure 1.

Empirical treatment should be initiated immediately after the diagnosis of SBP, in order to reduce complications and improve survival $[3,10,34]$. A diagnostic paracentesis is recommended 48 hours after initiation of treatment to verify the effectiveness of the first line of treatment. A $25 \%$ reduction in leukocyte counts is considered a good response to treatment. In contrast, bacterial resistance or secondary bacterial peritonitis should be considered $[3,34]$.

Albumin treatment is recommended by current guidelines in combination with antibiotic treatment at a dose of $1.5 \mathrm{~g} / \mathrm{kg}$ body weight on the first day of diagnosis followed by a dose of $1 \mathrm{~g} / \mathrm{kg}$ body weight on day 3 of diagnosis $[3,10]$. Sort and collaborators have shown that this combination of treatment has decreased the incidence of renal failure from $33 \%$ to $10 \%$, the in-hospital mortality rate from $29 \%$ to $10 \%$ and the mortality rate at 3 months after discharge from $41 \%$ to $22 \%$ compared to antibiotic monotherapy in patients with SBP [37].

An important aspect is related to the identification of the group of patients who would have important benefits from the administration of this treatment. Thus, the American Association for the Study of Liver Diseases (AASLD) guideline recommends treatment with albumin to patients with a creatinine value $>1 \mathrm{mg} / \mathrm{dL}$, blood urea nitrogen $(\mathrm{BUN})>30 \mathrm{mg} / \mathrm{dL}$ or total bilirubin $>4 \mathrm{mg} / \mathrm{dL}$ [13]. 
Initially it was believed that the only benefits of human albumin treatment were based on its ease of expanding intravascular volume, later it turned out that albumin is a multifunctional protein with antioxidant, immunomodulatory and detoxifying functions [38].

\section{CONCLUSIONS}

SBP remains one of the complications of liver cirrhosis, in which early diagnosis and effective treatment is a challenge. Although diagnostic paracentesis remains the cornerstone of
SBP diagnosis, it is not without complications and often cannot be achieved.

Thus, any delay in diagnosis and treatment means an increased risk of adverse events. For this reason, an attempt is made to identify diagnostic markers with high accuracy but given that the data are limited or contradictory they could not be validated. Another important aspect is the early and optimal treatment, for which the place where the infection was acquired must be taken into account, its severity and the local epidemiological situation regarding the resistance to antibiotics.

\begin{abstract}
Peritonita bacteriană spontană (PBS) este o complicație frecventă la pacienții cu ciroză hepatică, cu un risc crescut de mortalitate. Din acest motiv, efectuarea unei paracenteze în scop diagnostic ar trebui efectuată la toți pacienții cu ascită și tablou clinic cu înaltă suspiciune diagnostică. Deși datele din literatură abundă în identificarea unor markeri diagnostici din lichidul de ascită sau din sânge, aceștia nu au fost încă validați. Diagnosticul de certitudine necesită analiza lichidului de ascită și prezența de polimorfonucleare neutrofile $>250 \mathrm{~mm}^{3}$ in lichidul de ascită. Datele anterioare au arătat că cele mai frecvente microorganisme identificate erau reprezentate de bacteriile gram-negative, însă actual ne confruntăm cu o creștere a bacteriilor gram-pozitive și a bacteriilor multidrog rezistente. Deși tratamentul prompt şi eficient se impune cu scopul de a preveni evenimentele nefavorabile, acest lucru devine provocator având în vedere că terapiile de primă linie pot deveni ineficiente conducând la agravarea prognosticului și creșterea mortalității intraspitalicești. In această lucrare vom realiza o scurtă trecere în revistă a datelor existente cu privire la diagnosticul și tratamentul PBS.
\end{abstract}

Correspondence to: Roxana-Emanuela Popoiag, Faculty of Medicine, Ovidius University, 124 Mamaia Bvd., 900527 Constanța, Romania. E-mail: r.hulea@yahoo.com

Conflict of interest disclosure: The authors declare that there are not conflicts of interest.

\title{
REFERENCES
}

1. JALAN R, FERNANDEZ J, WIEST R, SCHNABL B, MOREAU R, ANGELI P, et al. Bacterial infections in cirrhosis: A position statement based on the EASL Special Conference 2013. Journal of Hepatology 2014;60(6):1310-1324.

2. PIANO S, SINGH V, CARACENI P, MSIWALL R, ALESSANDRIA C, FERNANFEZ J, et al. Epidemiology and effects of bacterial infections in patients with cirrhosis worldwide. Gastroenterology 2019;156: 1368-1380.

3. European Association for the Study of the Liver. EASL Clinical Practice Guidelines for the management of patients with decompensated cirrhosis. J Hepatol. 2018;69(2):406-460.

4. MARCIANO S, DIAZ JM, DIRCHWOLF M, GADANO A. Spontaneous bacterial peritonitis in patients with cirrhosis: incidence, outcomes, and treatment strategies. Hepat Med. 2019;11:13-22.

5. GAETANO JN, MICIC D, ARONSOHN A, REDDY G, TE H, REAU NS, et al. The benefit of paracentesis on hospitalized adults with cirrhosis and ascites. J Gastroenterol Hepatol. 2016;31:1025-1030.

6. KIM JJ, TSUKAMOTO MM, MATHUR AK, GHOMRI YM, HOU LA, SHEIBANI S, et al Delayed paracentesis is associated with increased in-hospital mortality in patients with spontaneous bacterial peritonitis. Am J Gastroenterol. 2014;109:1436-1442.

7. MACINTOSH T. Emergency Management of Spontaneous Bacterial Peritonitis - A Clinical Review. Cureus 2018;10(3):e2253.

8. MERCALDI CJ, LANES SF. Ultrasound guidance decreases complications and improves the cost of care among patients undergoing thoracentesis and paracentesis. Chest. 2013;143:532-538.

9. CHINNOCK B, AFARIAN H, MINNIGAN H, BUTLER J, HENDEY GW. Physician clinical impression does not rule out spontaneous bacterial peritonitis in patients undergoing emergency department paracentesis. Ann Emerg Med. 2008;52:268-273.

10. DEVER JB, SHEIKH MY. Review article: spontaneous bacterial peritonitis - bacteriology, diagnosis, treatment, risk factors and prevention. Aliment Pharmacol Ther.2015; 41:1116-1131. 
11. VAN DE GEIJN GM, VAN GENT M, VAN PUL-BOM N, BEUNIS MH, VAN TILBURG AJ, NJO TL. A new flow cytometric method for differential cell counting in ascitic fluid. Cytometry B Clin Cytom 2016;90:506-511.

12. SORIANO G, CASTELlOTE J, ALVAREZ C, GIRBAU A, GORDILlO J, BALIELLAS C, et al. Secondary bacterial peritonitis in cirrhosis: a retrospective study of clinical and analytical characteristics, diagnosis and management. J Hepatol. 2010;52:39-44.

13. RUNYON BA. American Association for the Study of Liver Diseases (AASLD) Practice Guidelines Committee. Management of Adult Patients with Ascites Due to Cirrhosis: Update 2012.

14. SHIZUMA T. Spontaneous bacterial and fungal peritonitis in patients with liver cirrhosis: A literature review. World J Hepatol. 2018;10(2):254-266.

15. VERMA R, SATAPATHY SK, BILAL M. Procalcitonin and C-reactive protein in the diagnosis of spontaneous bacterial peritonitis. Transl Gastroenterol Hepatol 2020.

16. YANG Y, Li L, QU C, ZENG B, LIANG S, LUO Z, et al. Diagnostic Accuracy of Serum Procalcitonin for Spontaneous Bacterial Peritonitis Due to End-stage Liver Disease: A Meta-analysis. Medicine (Baltimore). 2015;94(49):e2077.

17. LESINKA M, HARTLEB M, GUTKOWSKI K, NOWAKOWSKA-DULAWA E. Procalcitonin and macrophage inflammatory protein-1 beta (MIP-1 beta) in serum and peritoneal fluid of patients with decompensated cirrhosis and spontaneous bacterial peritonitis. Adv Med Sci. 2014;59:52-56.

18. GULER K, VATANSEVER S, KAYACAN SM, SALMAYENLI N, AKKAYA V, ERK O, et al. High sensitivity C-reactive protein in spontaneous bacterial peritonitis with nonneutrocytic ascites. Hepatogastroenterology. 2009;56(90):452-5.

19. KADAM N, ACHARYA S, SHUKLA S, GUPTA K. Ascitic Fluid High Sensitive C-Reactive Protein (hs-CRP). A Prognostic Marker in Cirrhosis with Spontaneous Bacterial Peritonitis. J Clin Diagn Res. 2016;10(4):OC20-4.

20. SHIZUMA T. Diagnostic Laboratory Markers for Spontaneous Bacterial Peritonitis. Ann Clin Lab Res. 2016; 4:4.

21. LEE SS, MIN HJ, CHOI JY, CHO HC, KIM JJ, LEE JM, et al. Usefulness of ascitic fluid lactoferrin levels in patients with liver cirrhosis. BMC Gastroenterol. 2016;16(1):132.

22. FERNANDES SR, SANTOS P, FATELA N, BALDAIA C, TATO MARINHO R, PROENCA H, et al. Ascitic Calprotectin is a Novel and Accurate Marker for Spontaneous Bacterial Peritonitis. J Clin Lab Anal. 2016;30(6):1139-1145.

23. DIBAS M, RAJAB AM, ZAGHLOUL MS, ATIAH MJ, ALJUNDI S, AMIR A, et al. Ascitic calprotectin for the diagnosis of spontaneous bacterial peritonitis: a systematic review and meta-analysis. Eur J Gastroenterol Hepatol. 2020;32(9):1075-1083.

24. KOULAOUZIDIS A. Diagnosis of spontaneous bacterial peritonitis: an update on leucocyte esterase reagent strips. World J Gastroenterol. 2011;17(9):1091-4.

25. KOULAOUZIDIS A, LEONTIADIS GI, ABDULLAH M, MOSCHOS J, GASEM J, THARAKAN J,et al. Leucocyte esterase reagent strips for the diagnosis of spontaneous bacterial peritonitis: a systematic review. Eur $\mathrm{J}$ Gastroenterol Hepatol. 2008;20:1055-1060.

26. ABDEL-RAZIK A, MOUSA N, ELBAZ S, EISSA M, ELHELALY R, ELDARS W. Diagnostic utility of interferon gammainduced protein $10 \mathrm{kDa}$ in spontaneous bacterial peritonitis: single-center study. Eur J Gastroenterol Hepatol. 2015;27:1087-1093.

27. ICHOU L, CARBONELL N, RAUTOU PE, LAURANS L, BOURCIER S, PICHEREAU C, et al. Ascitic fluid TREM-1 for the diagnosis of spontaneous bacterial peritonitis. Gut. 2016;65:536-538.

28. 28. KIM JK, CHON CY, KIM JH, KIM YJ, CHO JH, BANG SM, et al. Changes in serum and ascitic monocyte chemotactic protein-1 (MCP-1) and IL-10 levels in cirrhotic patients with spontaneous bacterial peritonitis. J Interferon Cytokine Res. 2007;27:227-230.

29. EL-TOUKHY N, EMAM SM. Diagnostic and Prognostic Values of Monocyte Chemotactic Protein-1 in Ascitic Fluid of Patients with Spontaneous Bacterial Peritonitis. Egypt J Immunol. 2016;23:17-27.

30. AGIASOTELLI D, ALEXOPOULOU A, VASILIEVA L, HADZIYANNIS E, GOUKOUS D, DAIKOS GL, et al. High serum lipopolysaccharide binding protein is associated with increased mortality in patients with decompensated cirrhosis. Liver Int. 2017;37:576-582.

31. CULLARO G, KIM G, PEREIRA MR, BROWN RS Jr, VERNA EC. Ascites Neutrophil Gelatinase-Associated Lipocalin Identifies Spontaneous Bacterial Peritonitis and Predicts Mortality in Hospitalized Patients with Cirrhosis. Dig Dis Sci. 2017;62:3487-3494.

32. ABDEL-RAZIK A, ELDARS W, ELHELALY R, ELDEEB AA, ABDELSALAM M, EL-WAK N, et al. Homocysteine: a new diagnostic marker in spontaneous bacterial peritonitis. Eur J Gastroenterol Hepatol. 2018;30(7):779-785.

33. BADAWI R, ASGHAR MN, ABD-ELSALAM S, ELSHWEIKH SA, HAYDARA T, Alnabawy SM, et al. Amyloid A in Serum and Ascitic Fluid as a Novel Diagnostic Marker of Spontaneous Bacterial Peritonitis. Antiinflamm Antiallergy Agents Med Chem. 2020;19(2):140-148.

34. European Association for the Study of the Liver. EASL clinical practice guidelines on the management of ascites, spontaneous bacterial peritonitis, and hepatorenal syndrome in cirrhosis. J Hepatol. 2010;53(3): 397-417.

35. MERLI M, LUCIDI C. Bacterial resistance in cirrhotic patients: An emerging reality. Journal of Hepatology. 2012; 56(4): 756-757.

36. FRIEDMAN ND, KAYE KS, STOUT JE, MCGARRY SA, TRIVETTE SL, BRIGGS JP, et al. Health care associated bloodstream infections in adults: a reason to change the accepted definition of community-acquired infections. Ann Intern Med 2002;137:791-797.

37. SORT P, NAVASA M, ARROYO V, ALDEGUER X, PLANAS R, RUIZ-DEL-ARBOL L, et al. Effect of intravenous albumin on renal impairment and mortality in patients with cirrhosis and spontaneous bacterial peritonitis. $\mathrm{N}$ Engl $\mathrm{J}$ Med. 1999;341:403-409.

38. GARCIA-MARTINEZ R, CARACENI P, BERNARDI M, GINES P, ARROYO V, JALAN R. Albumin: pathophysiologic basis of its role in the treatment of cirrhosis and its complications. Hepatology. 2013;58:1836-1846.

Received 8th May 2021 